\title{
Centella asiatica increases B-cell lymphoma 2 expression in rat prefrontal cortex
}

\author{
Kuswati*, Djoko Prakosa**, Brian Wasita***, and Nanang Wiyono****
}

\begin{abstract}
*Department of Anatomy, Faculty of Medicine, Islamic University of Indonesia **Department of Anatomy, Embryology and Anthropology, Faculty of Medicine

Gadjah Mada University.

***Department of Pathological Anatomy,

Faculty of Medicine,

Sebelas Maret University

****Department of Anatomy,

Faculty of Medicine,

Sebelas Maret University

\section{Correspondence}

dr. Kuswati, M.Sc

Department of Anatomy,

Faculty of Medicine,

\section{BACKGROUND}

Stress is one of the factors that cause apoptosis in neuronal cells. Centella asiatica has a neuroprotective effect that can inhibit apoptosis. This study aimed to examine the effect of Centella asiatica ethanol extract on Bcell lymphoma 2 (Bcl-2) protein expression in the prefrontal cortex of rats.

\section{METHODS}

An experimental study was conducted on 34 brain tissue samples from male Sprague Dawley rats exposed to chronic restraint stress for 21 days. The samples were taken from following groups: non-stress group K, negative control group P1 (stress + arabic gum powder), P2 (stress + C.asiatica at $150 \mathrm{mg} / \mathrm{kgBW}$ ), P3 (stress + C.asiatica at $300 \mathrm{mg} / \mathrm{kg} \mathrm{BW),}$ $\mathrm{P} 4$ (stress + C.asiatica at $600 \mathrm{mg} / \mathrm{kg}$ body weight) and positive control group P5 (stress + fluoxetine at $10 \mathrm{mg} / \mathrm{kgBW}$ ). The samples were made into sections that were stained immunohistochemically using Bcl-2 antibody to determine the percentage of cells expressing Bcl-2. Data were analyzed using one way ANOVA test followed by a post - hoc test.
\end{abstract}

Islamic University of Indonesia

Yogyakarta 55281

Phone: +6285228478487

Email: kuswati2005@yahoo.com

Univ Med 2015;34:10-6

DOI: 10.18051/UnivMed.2016.v35.10-16

pISSN: 1907-3062 / eISSN: 2407-2230

This open access article is distributed under a Creative Commons Attribution-Non Commercial-Share Alike 4.0 International License

\section{RESULTS}

There were significant differences in mean Bcl-2 expression between the groups receiving Centella asiatica compared with the non-stress group and stress-only group (negative control group) $(\mathrm{p}<0.05)$. The results were comparable to those of the fluoxetine treatment group.

\section{CONCLUSION}

The Centella asiatica ethanol extract was able to increase Bcl-2 expression in the prefrontal cortex of Sprague Dawley rats exposed to restraint stress. This study suggests that Centella asiatica may be useful in the treatment of cerebral stress.

Keywords : Centella asiatica, B-cell lymphoma 2, prefrontal cortex, stress, rat 


\section{Centella asiatica meningkatkan ekspresi protein B-cell lymphoma 2 pada korteks prefrontalis tikus}

\section{ABSTRAK}

\section{LATAR BELAKANG}

Stres merupakan salah satu faktor yang dapat menyebabkan apoptosis pada sel saraf. Centella asiatica memiliki efek neuroprotektif yang dapat menghambat apoptosis. Penelitian ini bertujuan untuk menilai peningkatan ekspresi protein B-cell lymphoma 2 (Bcl-2) setelah pemberian ekstrak etanol Centella asiatica pada tikus yang diberi perlakuan stres restraint kronik.

\section{METODE}

Sebuah penelitian eksperimental dilakukan pada 34 jaringan otak tikus Sprague Dawley yang diberi perlakuan stres restraint kronik selama 21 hari. Jaringan otak tikus berasal dari 6 kelompok berikut: kelompok non stres $(K)$, kelompok kontrol negatif stres + pulvis gumma arabicum (P1), kelompok stres + C.asiatica dosis $150 \mathrm{mg} / \mathrm{kgBB}$ $(P 2)$, kelompok stres + C.asiatica dosis $300 \mathrm{mg} / \mathrm{kgBB}(P 3)$, kelompok stres + C.asiatica dosis $600 \mathrm{mg} / \mathrm{kgBB}(P 4)$ dan kelompok stres + fluoksetin dosis $10 \mathrm{mg} / \mathrm{kgBB}$ sebagai kontrol positif (P5). Jaringan otak tersebut dibuat preparat yang dicat secara imunohistokimia untuk penghitungan prosentase sel yang mengekspresikan Bcl-2. Data yang diperoleh dianalisis menggunakan uji one way ANOVA dilanjutkan analisis post-hoc test.

\section{HASIL}

Terdapat perbedaan bermakna pada rerata prosentase ekspresi Bcl-2 antara kelompok yang mendapat terapi Centella asiatica dan fluoksetin dibandingkan dengan stres ( $p<0,05)$. Ekspresi Bcl-2 pada kelompok yang mendapat terapi Centella asiatica dan kelompok fluoksetin lebih tinggi dibanding kelompok stres.

\section{KESIMPULAN}

Ekstrak etanol Centella asiatica dapat dapat meningkatkan ekspresi protein antiapoptosis Bcl-2 di cortex prefrontalis tikus Sprague Dawley yang diberi perlakuan stres restraint kronik. Centella asiatica dapat berperan sebagai pengobatan pada restraint stress yang dialami tikus.

Kata Kunci : Centella asiatica, B-cell lymphoma 2, cortex prefrontalis, stres, tikus

\section{INTRODUCTION}

Stress can cause disorders of cell homeostasis, because it increases the secretion of glucocorticoids. In the central nervous system, an increase in glucocorticoids will trigger release of glutamate. The latter binds to N-methyl-Daspartate (NMDA) receptors, resulting in the opening of calcium channels, with subsequent calcium entry into the cytoplasm and increase in cytoplasmic free calcium. The entry of calcium and water into the mitochondria results in mitochondrial edema, impaired balance between
Bcl-2-associated X protein (Bax) and B-cell lymphoma 2 (Bcl-2) expression, increase in mitochondrial membrane permeability and release of cytochrome c, triggering apoptosis. ${ }^{(1)}$

Stress affects several areas of the prefrontal cortex, hippocampus, amygdala and brainstem. In the prefrontal cortex, stress results in a decrease in the activity of neurons, a reduction in the number of dendrites and shortening of dendrites in the medial prefrontal cortex. ${ }^{(2)}$ Chronic stress results in retraction of the apical dendrites of pyramidal cells in layer II / III and $\mathrm{V}$ of the medial prefrontal cortex.$^{(3)}$ Therefore, 
individuals who experience stress should be given therapy to prevent apoptosis and morphological changes in the prefrontal cortex.

Drugs that can be used to inhibit apoptosis in the central nervous system caused by stress belong to the class of antidepressant drugs. Olanzapine, imipramine, amitriptyline, citalopram and fluoxetine can inhibit apoptosis by increasing the expression of Bcl-2 and B-cell lymphomaextra large (Bcl-xl) and decreasing the expression of Bax. ${ }^{(4,5)}$ Although they may inhibit apoptosis, antidepressant drugs have many side effects. Side effects of tricyclic antidepressant drugs include dry mouth, dizziness, decreased vision, constipation, sedation, orthostatic hypotension and tachycardia. One class of antidepressant drug, the selective serotonin reuptake inhibitors (SSRIs), have side effects such as nausea, sleep disturbances, sexual dysfunction, changes in appetite, headache and dry mouth. ${ }^{(6)}$ Therefore, it is necessary to find an alternative drug to inhibit apoptosis, one of which can be found in the class of herbs such as pegagan (Centella asiatica).

Centella asiatica has a wide therapeutic dose range. Centella asiatica extract at a dose of $100-1000 \mathrm{mg} / \mathrm{kg}$ body weight did not cause any side effects, and had a median lethal dose (LD50) of more than $4000 \mathrm{mg} / \mathrm{kg}$ body weight. Centella asiatica extract up to a dose of 4000 $\mathrm{mg} / \mathrm{kg}$ did not result in impaired liver and kidney function as well as changes in the macroscopic picture of the liver, lung and kidney. ${ }^{(7)}$ Centella asiatica contains madecassoside, asiaticoside, asiatic acid and madecassic acid which have antioxidant and neuroprotectant effects. ${ }^{(8)}$ Administration of $C$. asiatica extract in mice with stress can improve spatial memory, increase hippocampal Cornu Ammonis (CA) 1 pyramidal layer thickness, and increase the number of neuroglia in the hippocampus. ${ }^{(9,10)}$ The objective of this study was to evaluate the anti-apoptotic effects of $C$. asiatica ethanol extract, in particular on the expression of $\mathrm{Bcl}-2$ in the prefrontal cortex of rats exposed to chronic restraint stress.

\section{METHODS}

\section{Research design}

This study is part of an umbrella research using an experimental design to evaluate the effect of Centella asiatica ethanol extract on memory, apoptosis and blood biochemistry (corticosteroid hormone levels and interleukins). The present study was limited to the examination of Bcl-2 protein expression in the prefrontal cortex of Sprague Dawley rats. The study period was from August 2012 until September 2013.

\section{Research subjects}

The sample size was determined from a mean difference in $\mathrm{Bcl}-2$ expression between groups of $9.0 \%$, with $\sigma=0.05$ and $\beta=0.2$, yielding 6 subjects per group. Therefore the total sample size for 6 groups was 36. ${ }^{(11)}$ The subjects were 34 brain tissue samples from male Sprague Dawley rats exposed to chronic restraint stress for 21 days. The samples were taken from 6 experimental groups consisting of a non-stress group (K), a negative control group exposed to stress + arabic gum powder ( 1 1), 3 groups exposed to stress $+C$. asiatica at dosages of $150 \mathrm{mg} / \mathrm{kg}$ body weight (P2), $300 \mathrm{mg} / \mathrm{kg}$ body weight (P3), and $600 \mathrm{mg} / \mathrm{kg}$ body weight (P4), respectively, and the positive control group exposed to stress + fluoxetine at a dosage of 10 $\mathrm{mg} / \mathrm{kg}$ body weight (P5). In the present study chronic restraint stress was used, by placing the rats into plastic transparent acrylic restraint tubes of $15 \mathrm{~cm}$ length and $5.5 \mathrm{~cm}$ diameter, with a number of $3 \mathrm{~mm}$ diameter holes at their closed ends. This treatment caused the rats to be immobilized, resulting in psychological stress.

Starting from day 1 , the stress groups were exposed to restraint stress by placing them into the restraint tubes daily for 6 hours, from 09.00 to 15.00 , for 21 days. In the stress groups receiving $C$. asiatica or fluoxetine, the treatments were given by gavage at predetermined dosages, 30 minutes before being stressed. The non-stress and stress control groups were given arabic gum powder for 21 days. On day 23 the rats were 
terminated and perfused, followed by taking brain tissue samples. Subsequently the samples were made into paraffin blocks, sliced on a microtome, and stained immunohistochemically with Bcl-2 antibody.

\section{Preparation of Centella asiatica extract}

C. asiatica was obtained in simplicia form from CV. Merapi Farma Herbal (a commercial herbal manufacturer). C. asiatica identification was performed in the Plant Systematics Laboratory, Faculty of Biology, Gadjah Mada University. The Centella asiatica extract was standardized nonspecifically by examination of of its water content and specifically by determining its asiaticoside content by thin layer chromatography. The $C$. asiatica extract contained $4.16 \pm 0.51 \%$ asiaticoside. The $C$. asiatica extract was diluted to give three concentrations of $30 \mathrm{mg} / \mathrm{ml}, 60 \mathrm{mg} / \mathrm{ml}$ and 120 $\mathrm{mg} / \mathrm{ml}$, respectively. These concentrations were used to prepare the three treatment dosages of $150 \mathrm{mg} / \mathrm{kg}, 300 \mathrm{mg} / \mathrm{kg}$ body weight and $600 \mathrm{mg} /$ $\mathrm{kg}$, respectively. Dilution of the extract was performed once in three days at the Laboratory of Pharmacology, Medical Faculty, Gadjah Mada University. The dilutions were stored in the refrigerator. To calculate the volume of the $C$. asiatica extract for each of the rats, the following formula was used:

Volume $=$ dose $(\mathrm{mg} / \mathrm{kgBW}) \times$ weight $(\mathrm{kg}) /$ concentration $(\mathrm{mg} / \mathrm{mL})$.

\section{Immunohistochemical staining}

Paraffin blocks were made from the brain tissue and then cut into $4 \mu \mathrm{m}$-thick sections. The cut brain areas comprised the prelimbic, infralimbic and cyngulate cortex at Bregma 3.72 $\mathrm{mm}$ to $2.52 \mathrm{~mm}$. ${ }^{(12)}$ Five sections were made from each rat brain at $50 \mu \mathrm{m}$ spacings. The first step in immunohistochemical staining consisted of deparaffinizing the sections using xylol and descending alcohol series. The tissue sections were then incubated in $3 \% \mathrm{H}_{2} \mathrm{O}_{2}$ in $10 \%$ methanol for 20 minutes and rinsed 3 times with phosphate buffered saline (PBS).
The tissue sections were blocked by Background Sniper blocking reagent for 10 minutes. Without rinsing, the tissue sections were incubated overnight at $4^{\circ} \mathrm{C}$ with anti-Bcl-2 primary antibody (1:400) (Bioworld No. BS1511). The following day, the sections were rinsed using PBS 2 times, $0.2 \%$ Tween 2 times and PBS 2 times. The sections were incubated in Trekki Universal Link, followed by incubation with horseradish peroxidase-conjugated streptavidin for 10 minutes. The tissue sections were again rinsed using PBS 2 times, $0.2 \%$ Tween 2 times and PBS 2 times. The final color product for single labeling was typically visualized by immersion in 3,3'-diaminobenzidin (1:100) solution for 5 minutes, rinsed 5 times with distilled water, counterstained with Meyer's hematoxylin for 1 minute, and rinsed with tap water for 2 minutes. The sections were then dehydrated in an ascending alcohol series $(70 \%$, $80 \%, 90 \%, 95 \%$ and $100 \%$ ) for 1 minute each, cleared with xylene, and then covered with canada balsam and cover slip.

\section{Measurements}

For each slide, cell counts were performed on 500 or more cells. The percentage of cells expressing Bcl-2 was calculated as the number of cells expressing Bcl-2 divided by the total number of cells multiplied by $100 \%$.

\section{Ehical clearance}

This study has received ethical clearance from the Ethics Committee, Faculty of Medicine, Gadjah Mada University, under number KE/FK/ 399/EC.

\section{Statistical analysis}

Tests of normality showed that the percentage data were normally distributed, therefore one-way ANOVA was performed to compare the mean number of cells between groups, followed by a post-hoc test to determine differences between specific groups. The critical level for rejection of the null hypothesis was considered to be a $\mathrm{p}$ value of 0.05 . 
Table 1. Mean Bcl-2 expression by treatment groups

\begin{tabular}{lccccccc}
\hline & \multicolumn{7}{c}{ Treatment grous } \\
\cline { 2 - 7 } & K (n=5) & P1 (n=6) & P2 (n=6) & P3 (n=6) & P4 (n=6) & P5 (n=5) & P \\
\hline Bc1-2 expression (\%) & $1.41 \pm$ & $5.00 \pm$ & $24.89 \pm$ & $21.91 \pm$ & $25.31 \pm$ & $21.84 \pm$ & 0.000 \\
& 0.32 & 1.12 & 5.11 & 4.52 & 5.84 & 4.37 & \\
\hline
\end{tabular}

$\mathrm{K}$ : control; P1: stress only; P2: stress $+C$. asiatica dosage of $150 \mathrm{mg} / \mathrm{kg}$ body weight; P3: stress $+C$. asiatica dosage of $300 \mathrm{mg} / \mathrm{kg}$ body weight; P4: stress + C. asiatica dosage of $600 \mathrm{mg} / \mathrm{kg}$ body weight; P5: stress + fluoxetine dosage of $10 \mathrm{mg} /$ $\mathrm{kg}$ body weight

\section{RESULTS}

A total of 34 rats were analyzed, because two rats died during the study. The mean expression of the anti-apoptotic protein Bcl-2 in the non-stress group was $1.41 \pm 0.32 \%$. Mean $\mathrm{Bcl}-2$ expression in this group was the lowest compared to the other groups. Mean Bcl-2 expression in the stress-only group (P1) was 5.00 $\pm 1.12 \%$, which was higher than that in the nonstress group, but lower than in the groups receiving therapy (group P2, P3, P4, P5). Groups $\mathrm{P} 2, \mathrm{P} 3$, and $\mathrm{P} 4$, receiving $C$. asiatica ethanol extract at a dose of $150 \mathrm{mg}, 300 \mathrm{mg}$, and 600 $\mathrm{mg}$, respectively, had mean Bcl-2 expression values of $24.89 \pm 5.11 \%, 21.91 \pm 4.52 \%$ and $25.31 \pm 5.84 \%$, respectively. The mean expression of $\mathrm{Bcl}-2$ in the group receiving fluoxetine (P5) was $21.84 \pm 4.37 \%$. Thus, the groups that received $C$. asiatica ethanol extract and fluoxetine showed higher Bcl-2 expression than the non-stress group $\mathrm{K}$ and the stress-only group P1. The results of the one-way ANOVA test showed significant differences in the expression of Bcl-2. To find out between which groups there was a significant difference, followup analysis using a post-hoc test was performed. The latter showed significant differences between the stress-only group P1 on the one hand, and the groups treated with $C$.asiatica ethanol extract and fluoxetine (P2, P3, P4, P5 ) on the other hand, with $p$-values of 0.000 to $0.002(p<0.05)$ (Table1).

Results of multiple comparisons analysis showed that the control group (K) was significantly different from the groups exposed to respectively stress $+C$. asiatica dosage of
$150 \mathrm{mg} / \mathrm{kg}$ body weight (P2), stress + C.asiatica dosage of $300 \mathrm{mg} / \mathrm{kg}$ body weight (P3), stress + C. asiatica dosage of $600 \mathrm{mg} / \mathrm{kg}$ body weight (P4) and stress + fluoxetine dosage of $10 \mathrm{mg} / \mathrm{kg}$ body weight (P5). Group P1 was significantly different from the groups exposed to respectively stress + C. asiatica dosage of $150 \mathrm{mg} / \mathrm{kg}$ body weight (P2), stress $+C$. asiatica dosage of 300 $\mathrm{mg} / \mathrm{kg}$ body weight $(\mathrm{P} 3)$, stress $+C$. asiatica dosage of $600 \mathrm{mg} / \mathrm{kg}$ body weight (P4) and stress + fluoxetine dosage of $10 \mathrm{mg} / \mathrm{kg}$ body weight (P5). There were no significant differences between the groups exposed to stress $+C$. asiatica dosage of $150 \mathrm{mg} / \mathrm{kg}$ body weight (P2), stress + C.asiatica dosage of $300 \mathrm{mg} / \mathrm{kg}$ body weight $(\mathrm{P} 3)$, stress + C. asiatica dosage of 600 $\mathrm{mg} / \mathrm{kg}$ body weight $(\mathrm{P} 4)$ and stress + fluoxetine dosage of $10 \mathrm{mg} / \mathrm{kg}$ body weight (P5) (Table 2).

Table 2. Post-hoc analysis of Bcl-2 expression percentages between groups

\begin{tabular}{|c|c|c|c|}
\hline & \multicolumn{2}{|c|}{$\begin{array}{l}\text { 95\% sign ifican ce } \\
\text { index }\end{array}$} & \multirow[t]{2}{*}{$\mathbf{p}$} \\
\hline & $\begin{array}{l}\text { Lower } \\
\text { bound }\end{array}$ & $\begin{array}{l}\text { Upper } \\
\text { bo und }\end{array}$ & \\
\hline $\mathrm{K}$ vs P 1 & -18.32 & 6.63 & 0.483 \\
\hline $\mathrm{K} v \mathrm{P} 2$ & -33.70 & -13.26 & $0.001 *$ \\
\hline $\mathrm{K}$ vs P 3 & -30.73 & -10.28 & $0.001 *$ \\
\hline $\mathrm{K}$ vs $\mathrm{P} 4$ & -34.13 & -13.68 & $0.001 *$ \\
\hline $\mathrm{K}$ vs P 5 & -31.11 & -9.76 & $0.001 *$ \\
\hline $\mathrm{P} 1 \mathrm{vs} \mathrm{P} 2$ & -29.63 & -10.14 & $0.002 *$ \\
\hline $\mathrm{P} 1 \mathrm{vsP} 3$ & -26.66 & -7.16 & $0.001 *$ \\
\hline P1 vs P4 & -20.06 & -10.56 & $0.004 *$ \\
\hline P1 vs P5 & -27.06 & -6.62 & $0.001 *$ \\
\hline $\mathrm{P} 2 \mathrm{vsP} 3$ & -6.77 & 12.72 & 0.547 \\
\hline $\mathrm{P} 2$ vs $\mathrm{P} 4$ & -10.17 & 9.32 & 0.932 \\
\hline $\mathrm{P} 2$ vs P5 & -7.18 & 13.27 & 0.556 \\
\hline $\mathrm{P} 3 \mathrm{vsP} 4$ & -13.15 & 6.35 & 0.483 \\
\hline P3 vs P5 & -10.15 & 10.30 & 0.994 \\
\hline P4 vs P5 & -6.75 & 13.70 & 0.496 \\
\hline
\end{tabular}

*The mean difference is significant at the 0.05 level 


\section{DISCUSSION}

In this study, stress-exposed rats showed higher expression of $\mathrm{Bcl}-2$ than did rats not exposed to stress. Differences in Bcl-2 expression between both groups were not significant. Research conducted by Kim et al. ${ }^{(13)}$ found that rats exposed to restraint stress, noise stress and cold stress for 10 days showed impaired memory and higher expression of Bcl2, Bax and caspase-3 than non-stressed rats. Increased Bcl-2 expression was presumably a compensatory mechanism for neuronal protection from exposure to stress. ${ }^{(14)}$

In the present study, the expression of Bcl2 in the stress-only group (P1) was lower than in the groups treated with $C$. asiatica and fluoxetine (group P2, P3, P4 and P5). Treatment with ethanol extract of $C$. asiatica at a dose of $150 \mathrm{mg} / \mathrm{kg}$ body weight, $300 \mathrm{mg} / \mathrm{kg}$ body weight and $600 \mathrm{mg} / \mathrm{kg}$ body weight could increase the expression of Bcl-2 protein. Dose differences did not result in significantly different expression of $\mathrm{Bcl}-2$ protein. This result shows that the ethanol extract of $C$. asiatica can provide neuroprotective effects by inhibiting apoptosis through increased expression of $\mathrm{Bcl}-2$ protein. This result is consistent with research conducted by Uvarajan et al. ${ }^{(15)}$ and Omar et al. ${ }^{(16)}$ who reported that the administration of asiaticoside at a dose of $50 \mathrm{mg} / \mathrm{kg}$ for 21 days can increase the expression of $\mathrm{Bcl}-2$ protein and decrease the expression of Bax protein in the striatum and midbrain in rats with induced 1-methyl-4-phenyl1,2,3,6-tetrahydropyridine (MPTP) neurotoxicity. In our study, there were no significant differences in the mean expression of the $\mathrm{Bcl}-2$ protein between the groups that received ethanol extract of C.asiatica and the group on fluoxetine. Administration of fluoxetine at a dose of $10 \mathrm{mg} / \mathrm{kg}$ body weight could increase the expression of $\mathrm{Bcl}-2$ protein in the prefrontal cortex of rats exposed to chronic restraint stress.

The results are consistent with research by Kosten et al. ${ }^{(17)}$ which states that the administration of fluoxetine at a dose of $5 \mathrm{mg} /$ $\mathrm{kg}$ for 21 days in rats exposed to repeated unpredictable stress increases Bcl-2 mRNA in the cingulate, frontal, and lateral parietal cortex. The study by Guirado et al. ${ }^{(18)}$ showed that in middle-aged rats chronic fluoxetine treatment induces changes in the expression of molecules related to neuronal structural plasticity. A previous study has clearly shown that intraperitoneal injections per se of fluoxetine in rats have effects on the structure of neurons after chronic stress. ${ }^{(19)}$

In the present study some of the rats died from gavaging trauma and some paraffin blocks were damaged due to blunted microtome knifes and fatigue of the investigators. We also experienced difficulties in determining the limits of the medial prefrontal cortex, although we were guided by the atlas of the rat brain by Paxinos and Watson. ${ }^{(12)}$

Further researches are required to determine the expression of the Bax pro-apoptotic protein, and the $\mathrm{Bax} / \mathrm{Bcl}-2$ ratio. In addition, further researches are needed to examine other parameters such as the expression of active caspase- 3 and TUNEL assay.

\section{CONCLUSION}

Ethanol extract of $C$. asiatica could increase the expression of Bcl-2 protein in the prefrontal cortex of Sprague Dawley rats exposed to chronic restraint stress. This study suggests that Centella asiatica may be useful in the treatment of cerebral stress.

\section{ACKNOWLEDGMENTS}

The authors would like to thank the Faculty of Medicine, Islamic University of Indonesia, Prof. Dr. Mustofa, M.Kes. Apt and dr. Dwi Cahyani Ratnasari, M.Kes. PA(K) for all advice given. We also thank Rina Susilowati M.D. Ph.D as laboratory supervisor for her support. Thanks are also due to Anggraini Janar Wulan, Rizal Adi Kusnomo, and Suparno of the Department of Physiology, Faculty of Medicine, Gadjah 
Mada University, and to Sumaryati of the Department of Histology and Cellular Biology, Faculty of Medicine, Gadjah Mada University, for their technical assistance.

\section{REFERENCES}

1. Chen SD, Yang DI, Lin TK, et al. Roles of oxidative stress, apoptosis, PGC- $1 \alpha$ and mitochondrial biogenesis in cerebral ischemia. Int J Mol Sci 2011;12:7199-215.

2. Wilber AA, Walker AG, Southwood CJ, et al. Chronic stress alters neural activity in medial prefrontal cortex during retrieval of extinction. Neuroscience 2011;174:115-31.

3. Goldwater DS, Pavlides CP, Hunter RG, et al. Structural and functional alterations to rat medial prefrontal cortex following chronic restraint stress and recovery. Neuroscience 2009; 164:798808.

4. Murray F, Hutson PH. Hippocampal Bcl-2 expression is selectively increased following chronic but not acute treatment with antidepressants, 5-HT1A or 5-HT2C/2B receptor antagonists. Eur J Pharmacol 2007;569: 41-7.

5. Shiskina GT, Kalinina TS, Berezova IV, et al. Stress-induced activation of the brainstem Bcl$\mathrm{xl}$ gene expression in rats treated with fluoxetine: correlation with serotonin metabolism and depressive-like behavior. Neuropharmacology 2012;62:177-83.

6. Ferguson JM. SSRI antidepressant medications: adverse effects and tolerability. J Clin Psychiatry 2001;3:22-7.

7. Chauhan PK, Singh V. Acute and subacute toxicity study of the aceton leaf extract of Centella asiatica in experimental animal models. Asian Pac J Trop Bio 2012;2:511-3.

8. Kumar A, Dogra S, Prakash A. Neuroprotective effects of Centella asiatica against intracerebroventricular colchicine-induced cognitive impairment and oxidative stress. Int J Alzheimer Dis 2009. Article ID 972178, 8 pages, doi:10.4061/2009/972178.

9. Sari DCR. The relationship between memory, CA1 hippocampus and neuroglia after Centella asiatica leaf extract's administration in stress- induced rat (Rattus norvegicus), Proceeding of $2^{\text {nd }}$ International Joint Symposium Frontier In Biomedical Sciences: From Genes to Applications Faculty of Medicine Gadjah Mada University. Yogyakarta;2011.

10. Sari DCR, Aswin S, Suharmi S, et al. The effect of Centella asiatica ethanolic extract's administration duration on spatial memory in rat (Rattus norvegicus) after electric-stress induced. Mutiara Medika Jurnal Kedokteran Kesehatan 2011;3:1-10.

11. Charan J, Kantharia ND. How to calculate sample size in animal studies? J Pharmacol Pharmacother 2013;4:303-6. doi: 10.4103/0976500X.119726

12. Paxinos G, Watson $C$. The rat brain. $6^{\text {th }}$ ed. Philadelphia: Elsevier Inc.;2007.p.11-8.

13. Kim BK, Ko IG, Kim SE, et al. Impact of several types of stresses on short-term memory and apoptosis in the hippocampus of rats. Int Neurourol J 2013;17:114-20.

14. Tan ML, Ooi JP, Ismail N, et al. Programmed cell death pathways and current antitumor targets. Pharm Res 2009;26;7:1547-56.

15. Uvarajan S, Janardhanam VA, Gopinath G. Neuro-shielding effect of asiaticoside against MPTP induced variations in experimental mice. IJEST 2012;4:960-5.

16. Orhan IE. Centella asiatica (L.) Urban: from traditional medicine to modern medicine with neuroprotective potential. Evid Based Complement Alternat Med 2012;10:1-8.

17. Kosten, TA, Galloway MP, Duman RS, et al. Repeated unpredictable stress and antidepressants differentially regulate expression of the Bcl-2 family of apoptotic genes in rat cortical, hippocampal and limbic brain structures. Neuropsychopharmacology 2008;33: 1545-58.

18. Guirado R, Matarredona DS, Varea E, et al. Chronic fluoxetine treatment in middle aged rats induces changes in the expression of plasticity related molecules and in neurogenesis. BMC Neurosci 2012;5:1-13.

19. Huang GJ, Herbert J. Stimulation of neurogenesis in the hippocampus of the adult rat by fluoxetine requires rhythmic change in corticosterone. Biological Psychiatry 2006;59:619-24. 